\title{
Evaluasi Pengukuran Angin dan Arus Laut Pada Data Sentinel-1, Data Bmkg, dan Data In-Situ (Studi Kasus: Perairan Tenggara Sumenep)
}

\author{
Fristama Abrianto, Lalu Muhamad Jaelani \\ Jurusan Teknik Geomatika, Fakultas Teknik Sipil dan Perencanaan, Institut Teknologi Sepuluh Nopember (ITS) \\ Kampus ITS Sukolilo, Surabaya 60111 Indonesia \\ e-mail :lmjaelani@geodesy.its.ac.id
}

\begin{abstract}
Abstrak-Arus air laut merupakan pergerakan massa air secara vertikal dan horizontal sehingga menuju keseimbangannya, atau gerakan air yang sangat luas yang terjadi di seluruh lautan dunia. Arus juga merupakan gerakan mengalir suatu massa air karena tiupan angin atau perbedaan densitas atau pergerakan gelombang panjang. Pergerakan arus dipengaruhi oleh arah angin, perbedaan tekanan, perbedaan densitas air, gaya Coriolis dan arus ekman, topografi dasar laut, arus permukaan, upwelling, dan downwelling.

Penelitian ini dilakukan di daerah Perairan Tenggara Sumenep untuk mendapatkan data berupa estimasi angin dan arus laut. Dengan metode ekstraksi fitur pada Citra SAR, didapatkan hasil berupa estimasi angin yang kemudian dilakukan pemodelan arus laut. Dari data tersebut dilakukan evaluasi hasil estimasi angin dan arus laut dari citra satelit SAR Sentinel-1, data model arus laut dari BMKG dan data arus laut secara in-situ.

Hasil ekstraksi fitur dari Citra Sentinel-1 didapatkan hasil ratarata angin pada 4 Februari 2016 sebesar $1,44 \mathrm{~m} / \mathrm{s}$ dengan arah menuju 292 ${ }^{\circ} 40^{\prime} 12$ ”; 16 April 2016 sebesar 0,99 m/s dengan arah menuju 265'16'12"; dan 25 April 2016 sebesar 3,76 m/s dengan arah menuju $264^{\circ} 25$ ' 12 '. Hasil pemodelan arus pada data Citra Sentinel-1 tanggal 4 Februari 2016 memiliki kecepatan rata-rata $0,18 \mathrm{~m} / \mathrm{s}$ dan arah $198^{\circ} 36^{\prime} 0^{\prime \prime}$; tanggal 16 April 2016 memiliki kecepatan rata-rata $0,08 \mathrm{~m} / \mathrm{s}$ dengan arah $132^{\circ} 22^{\prime} 47,9$ '; tanggal 25 April 2016 memiliki rata-rata kecepatan $0,95 \mathrm{~m} / \mathrm{s}$ dengan arah rata-rata 92 3'36”.
\end{abstract}

Kata Kunci - Arus Laut, Estimasi Angin, SAR, Sentinel-1

\section{PENDAHULUAN}

$\mathrm{N}$ EGARA Kesatuan Republik Indonesia merupakan negara maritim yaitu negara yang memiliki perairan luas. Wilayah Indonesia terbentang sepanjang 3.977 mil di antara Samudra Hindia dan Samudra Pasifik. Luas daratan Indonesia adalah $1.922 .570 \mathrm{~km}^{2}$ sementara luas perairannya 3.257 .483 $\mathrm{km}^{2}$ [1]. Dewasa ini arus laut banyak dimanfaatkan untuk berbagai keperluan yang menunjang kehidupan manusia, akan tetapi penelitian tentang arus laut itu sendiri masih sedikit dilakukan.

Arus air laut merupakan pergerakan massa air secara vertikal dan horizontal sehingga menuju keseimbangannya, atau gerakan air yang sangat luas yang terjadi di seluruh lautan dunia [2]. Arus juga merupakan gerakan mengalir suatu massa air yang dikarenakan tiupan angin atau perbedaan densitas atau pergerakan gelombang panjang [3]. Pergerakan arus dipengaruhi oleh beberapa hal antara lain arah angin, perbedaan tekanan air, perbedaan densitas air, gaya Coriolis dan arus
Ekman, topografi dasar laut, arus permukaan, upwelling, dan downwelling. Arus permukaan terjadi pada beberapa ratus meter dari permukaan, bergerak dengan arah horizontal dan dipengaruhi oleh pola sebaran angin.

Beberapa negara telah berhasil melakukan instalasi pembangkit listrik dengan memanfaatkan energi arus dan pasang surut, mulai dari prototype turbin pembangkit hingga mencapai turbin skala komersial dengan kapasitas 1,2 MW/turbin seperti yang dibangun di Skotlandia, Perancis, Norwegia, Inggris, Australia, Italia, Korea Selatan dan Amerika Serikat [4]. Pengukuran arus laut secara langsung memiliki beberapa kekurangan diantaranya masalah biaya, waktu, serta data yang diperoleh tidak memiliki resolusi spasial maupun temporal yang baik. Selain masalah tersebut, pengukuran arus secara langsung di lapangan mengandung resiko yang besar mengingat keadaan lautan Indonesia yang tidak menentu.

Pada 3 April 2014, Sentinel-1 mulai mengorbit bumi. Satelit ini merupakan satelit pertama dalam program observasi bumi Copernicus. Sentinel-1 bertugas mengamati iklim dan lingkungan [5]. Sentinel-1 dirancang untuk membawa satu kanal gelombang C-band. Sentinel-1 merupakan kesinambungan data dari misi ERS dan Envisat, dengan peningkatan dalam hal revisit time yang mencapai 12 hari dengan melewati ekuator dalam 3 hari, cakupan, ketepatan waktu dan keandalan pelayanan. Sentinel-1 dapat melakukan berbagai hal diantaranya pemantauan zona laut es lingkungan Arktik dan pengawasan lingkungan laut, pemantauan risiko gerak permukaan tanah. Sentinel-1 juga menyediakan informasi tentang angin dan gelombang yang berguna dalam penentuan interaksi antara gelombang dan arus. Selain itu, pengamatan tersebut dapat digunakan untuk melacak jalur dari tumpahan minyak dan polusi lainnya [6].

Dari kasus tersebut, kami melakukan penelitian di daerah Perairan Tenggara Sumenep dengan membandingkan hasil pengukuran dari citra satelit SAR Sentinel-1, data arus laut dari Badan Meteorologi, Klimatologi dan Geofisika (BMKG) dan data arus laut secara pengukuran in-situ. Dengan membandingkan hasil pengukuran tersebut diharapkan dapat dilakukan evaluasi hasil dari data citra Sentinel-1 dan data perekaman arus BMKG terhadap data pengukuran langsung lapangan yaitu data in-situ. 


\section{METODOLOGI PENELITIAN}

\section{A. Lokasi Penelitian}

Penelitian ini mengambil daerah studi di wilayah sekitar Pulau Poteran, Madura, yang terletak di antara koordinat $113^{\circ} 53$ '57" BT sampai $114^{\circ} 15^{\prime} 53^{\prime \prime}$ BT; BT7 3 '21,5” LS sampai $7^{\circ} 15^{\prime} 9,2^{\prime \prime} \mathrm{LS}$, dimana secara administratif terletak di Kabupaten Sumenep, dan terletak di tenggara kota Sumenep.

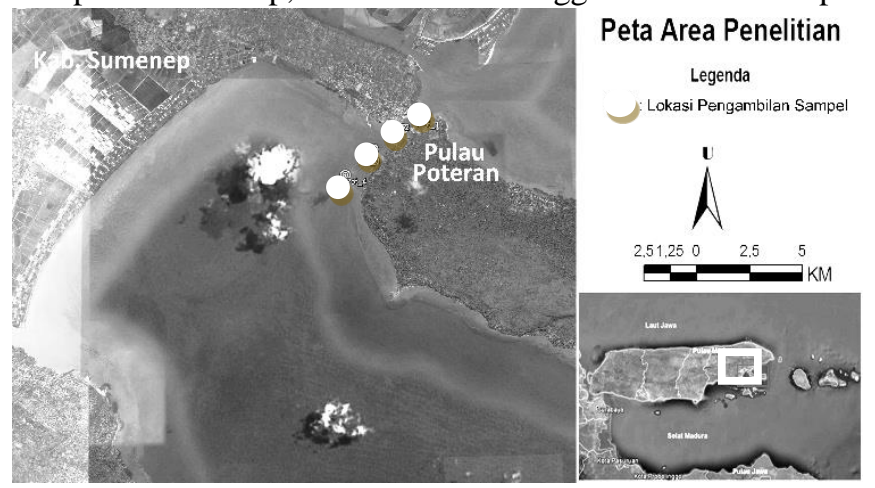

Gambar 1. Lokasi Penelitian

\section{B. Data dan Peralatan}

1) Data

Data primer yang digunakan pada penelitian ini adalah data citra satelit Sentinel-1 dengan waktu pengambilan beragam. Sedangkan data sekunder yang digunakan adalah data pemodelan arus laut dari BMKG dan hasil pengukuran arus di Pulau Poteran.

2) Peralatan

Peralatan yang digunakan dalam penelitian ini berupa perangkat lunak (software) dan perangkat keras (hardware). Perangkat lunak yang digunakan dalam pengerjaan peneliaan ini antara lain SNAP (Sentinel Application Platform) yang berguna dalam pengolahan citra radar. ArcGIS, berupa aplikasi untuk melakukan plotting dan pemodelan angin dan arus. OriginLab (Evaluation copy), merupakan perangkat lunak pengolahan data yang berguna untuk pembuatan Rose diagram.

Sementara peralatan keras lain yang digunakan terutama pada survei lapangan yaitu Current Meter, merupakan instrumen untuk mengukur arus, baik itu angin maupun arus laut. GPS Handheld atau navigasi, berguna untuk menentukan lokasi atau posisi koordinat pengambilan data. Kompas, sebagai alat pendukung yang berguna untuk menentukan arah angin dan arus laut.

\section{Tahap Pengolahan Data}

Tahap pengolahan data dapat dimulai dari data Sentinel-1, dilakukanlah proses pre-processing yang pertama berupa Apply orbit file untuk menyesuaikan citra dengan orbit satelit. Selanjutnya dilakukan kalibrasi radiometrik untuk mendapat output "sigma0_band". Langkah berikutnya yaitu SAR Multilooking untuk menormalkan ukuran piksel. Kemudian dilakukan koreksi geometrik yang sesuai dengan kondisi di lapangan. Setelah itu dilakukan konversi dari SLC (Single Look Complex) menjadi format GRD (Ground Range Detected). Langkah terakhir dalam pre-processing adalah pemotongan citra sesuai daerah penelitian.
Dari citra Sentinel Level 1 GRD dilakukanlah proses ekstraksi data estimasi angin dengan menggunakan metode Feature Extraction pada SNAP, sehingga diperoleh data berupa persebaran angin. Dari data estimasi angin dilakukan perhitungan dan pemodelan arus dengan menambahkan parameter lain seperti bathimetri, pasang surut dan data batas perairan.

Setelah mendapatkan nilai arus dan angin dilakukan evaluasi dan perbandingan pada data Sentinel-1, BMKG, dan in-situ. Selain itu dilakukanlah pembuatan peta estimasi angin dan arus laut sebagai luaran produk.

\section{HASIL DAN PEMBAHASAN}

\section{A. Hasil Wind Field Estimation}

Dari hasil ekstraksi fitur didapat wind field estimation, berupa data persebaran arah dan kecepatan angin dan data informasi log file. Dari data Citra Sentinel-1 tersebut didapatkan hasil rata-rata angin pada 4 Februari 2016 sebesar $0,99 \mathrm{~m} / \mathrm{s}$ dengan arah menuju $265^{\circ} 16^{\prime} 12^{\prime}$; 16 April 2016 sebesar 1,44 m/s dengan arah menuju 292 40'12"; dan 25 April 2016 sebesar $3,76 \mathrm{~m} / \mathrm{s}$ dengan arah menuju $264^{\circ} 25^{\prime} 12^{\prime \prime}$.

Hasil wind estimation dari proses ekstraksi fiturdapat dilihat pada gambar 2,3, dan 4 .

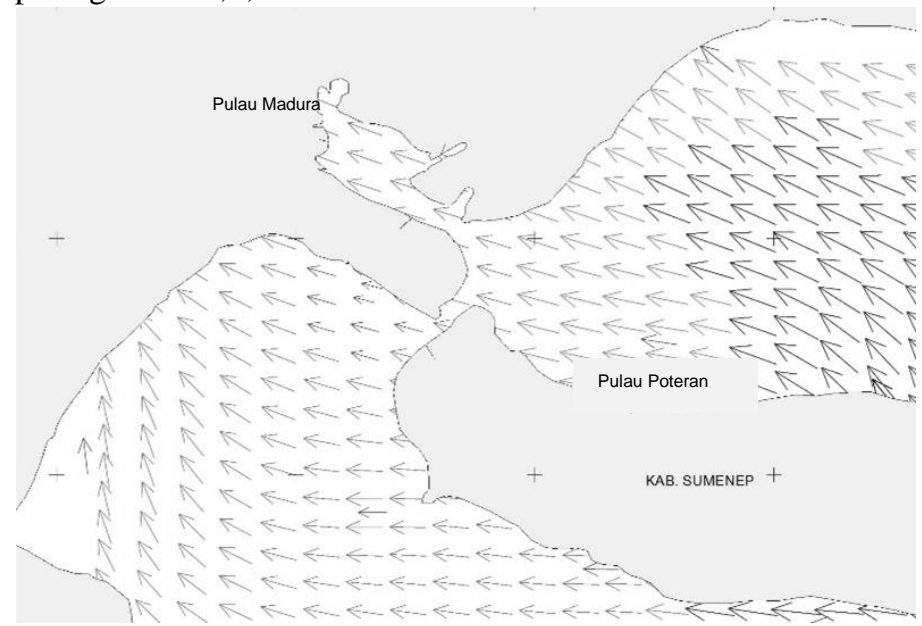

Gambar 2. Wind Estimation Citra Sentinel-1 pada 4 Februari

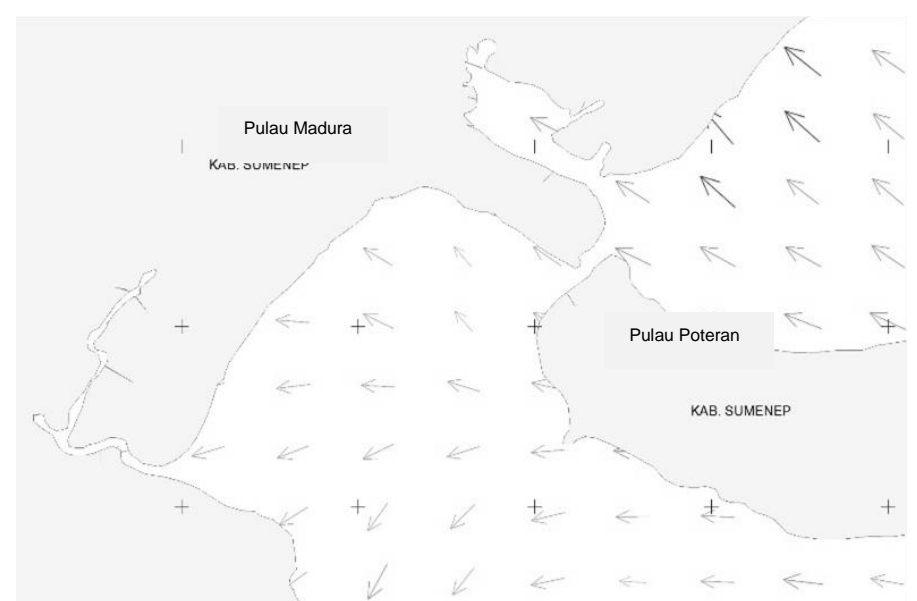

Gambar 3. Wind Estimation Citra Sentinel-1 pada 16 April 


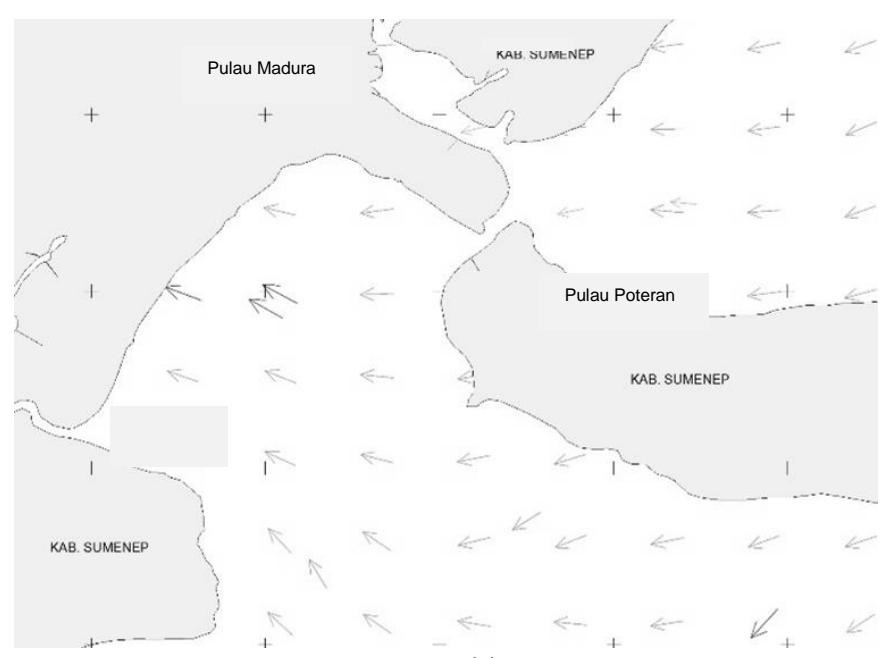

(c)

Gambar 4. Wind Estimation Citra Sentinel-1 pada 25 April

\section{B. Evaluasi Perbandingan Data}

\section{1) Perbandingan Data Angin}

Evaluasi dilakukan dengan membandingkan data Citra SAR Sentinel-1, data BMKG, dan data lapangan. Karena pada pengukuran lapangan, data Sentinel-1, dan data BMKG hanya 2 titik memiliki koordinat yang sama dari 3 titik sampel maka perbandingan dilakukan pada 2 titik tersebut. Selain itu, pengambilan data lapangan yang dilakukan tanggal 22 April 2016 tidak sama dengan orbit satelit Sentinel-1 sehingga satelit tidak melakukan perekaman data pada lokasi penelitian, maka citra Sentinel-1 tidak dapat dilakukan perbandingan dengan data lapangan dan hanya dibandingkan dengan data BMKG.

Tabel 1.

Hasil Perbandingan Angin Data In-situ dan Data BMKG

\begin{tabular}{ccccccc}
\hline \hline & \multicolumn{2}{c}{ Data In-situ } & \multicolumn{2}{c}{ Data BMKG } & \multicolumn{2}{c}{ Selisih } \\
\cline { 2 - 7 } $\begin{array}{c}\text { Nama } \\
\text { Titik }\end{array}$ & $\begin{array}{c}\text { Kec. } \\
(\mathrm{m} / \mathrm{s})\end{array}$ & $\begin{array}{c}\text { Arah } \\
(\text { derajat})\end{array}$ & $\begin{array}{c}\text { Kec. } \\
(\mathrm{m} / \mathrm{s})\end{array}$ & $\begin{array}{c}\text { Arah } \\
(\text { derajat })\end{array}$ & $\begin{array}{c}\text { Kec. } \\
(\mathrm{m} / \mathrm{s})\end{array}$ & $\begin{array}{c}\text { Arah } \\
(\text { derajat })\end{array}$ \\
\hline St-1 & 0,35 & 248,86 & 4,32 & 286,91 & 3,98 & 38,05 \\
St-4 & 0,34 & 268,57 & 4,23 & 287,02 & 3,89 & 18,45
\end{tabular}

Hasil dari perbandingan angin dari data in-situ dan data BMKG memiliki selisih nilai yang besar pada kecepatan yaitu pada St-1 sebesar 3,98 m/s dan titik 4 sebesar 3,89 m/s. Hal tesebut terjadi karena dalam pengukuran lapangan tidak selalu terdapat angin, misal mulai pukul 23.00-03.00 malam kecepatan angin $0 \mathrm{~m} / \mathrm{s}$.

Tabel 2.

Hasil Perbandingan Angin Data BMKG dan Data Sentinel-1

\begin{tabular}{|c|c|c|c|c|c|c|c|}
\hline \multirow{2}{*}{$\begin{array}{l}\text { Nama } \\
\text { Titik }\end{array}$} & \multirow[b]{2}{*}{ Tanggal } & \multicolumn{2}{|c|}{ BMKG } & \multicolumn{2}{|c|}{ Sentinel-1 } & \multicolumn{2}{|c|}{ Selisih } \\
\hline & & $\begin{array}{l}\mathrm{Kec} . \\
(\mathrm{m} / \mathrm{s})\end{array}$ & $\begin{array}{c}\text { Arah } \\
\text { (derajat) }\end{array}$ & $\begin{array}{l}\mathrm{Kec} . \\
(\mathrm{m} / \mathrm{s})\end{array}$ & $\begin{array}{c}\text { Arah } \\
\text { (derajat) }\end{array}$ & $\begin{array}{l}\mathrm{Kec} . \\
(\mathrm{m} / \mathrm{s})\end{array}$ & $\begin{array}{c}\text { Arah } \\
\text { (derajat) }\end{array}$ \\
\hline \multirow{3}{*}{ St-1 } & $4-2-2016$ & 2,21 & 153,6 & 0,60 & 285,71 & 1,61 & 132,16 \\
\hline & $16-4-2016$ & 2,62 & 270,7 & 1,27 & 296,76 & 1,35 & 26,08 \\
\hline & 24-4-2016 & 5,01 & 295,4 & 1,99 & 246,94 & 3,01 & 48,49 \\
\hline \multirow{3}{*}{ St-4 } & $4-2-2016$ & 2,16 & 15 & 0,51 & 284,14 & 1,64 & 130,56 \\
\hline & $16-4-2016$ & 2,55 & 270,3 & 0,80 & 305,79 & 1,75 & 35,49 \\
\hline & $24-4-2016$ & 4,85 & 295,5 & 1,87 & 245,06 & 2,98 & 50,42 \\
\hline
\end{tabular}

Hasil dari perbandingan angin dari data BMKG dan data Sentinel-1 pada tanggal perekaman 4 Februari, 16 April, 25
April memiliki selisih nilai yang besar pada kecepatan yang memiliki selisih waktu terbesar $3,01 \mathrm{~m} / \mathrm{s}$. Hal tesebut terjadi karena citra satelit Sentinel hanya beroperasi pada jam-jam tertentu (kontinu) sehingga tidak mencakup satu hari penuh (24 jam), sehingga ketika ada angin yang berhembus pada waktu selain waktu perekaman satelit tersebut maka tidak ada data perekaman pada sensor Sentinel-1.

Dari data perekaman angin tersebut, kami sajikan dalam bentuk diagram angin (Rose diagram) berikut.

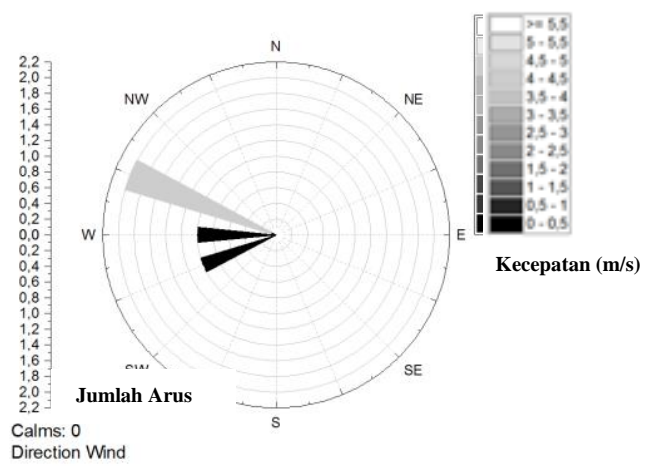

Gambar 5. Rose Diagram Data Angin In-situ dan BMKG

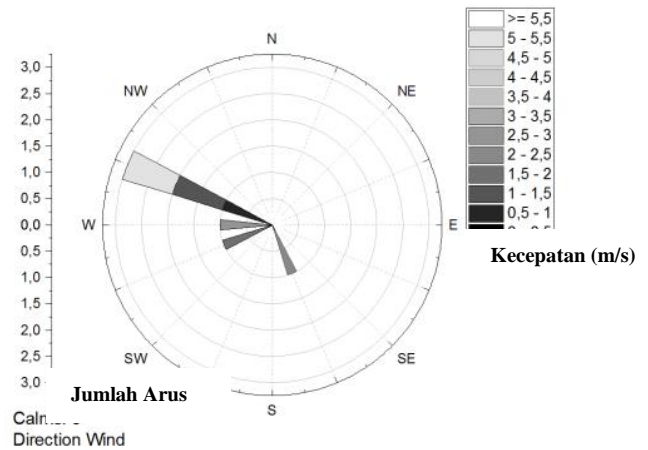

(a)

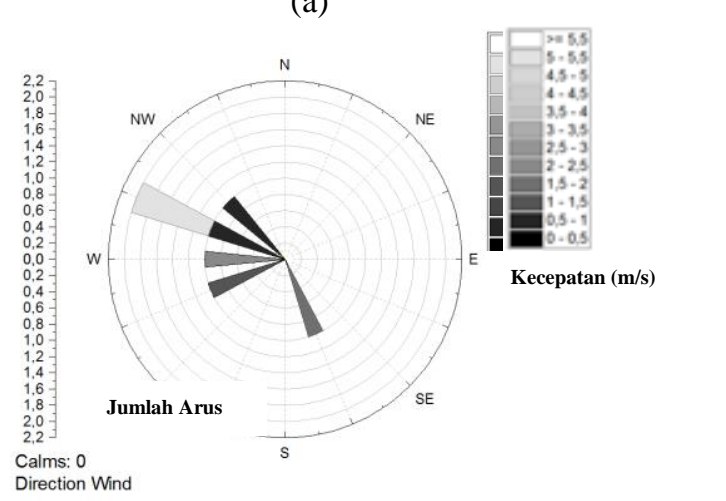

(b)

Gambar 6. Rose Diagram Data Angin BMKG dan Sentinel-1 (a) Lokasi Titik Point 1, (b) Lokasi Titik Point 4

2) Perbandingan Data Arus

Dalam penelitian ini, evaluasi arus dilakukan dengan membandingkan data BMKG, dan data lapangan saja karena data Sentinel-1 Level 1 tidak dapat melakukan ekstraksi arus secara langsung. Dari dua data tersebut hanya memiliki dua titik yang memiliki koordinat sama, maka hanya dilakukan perbandingan pada kedua sampel titik tersebut pada tanggal 22 April 2016. 
Tabel 3.

Hasil Perbandingan Arus Data In-situ dan Data BMKG

\begin{tabular}{ccccccc} 
& \multicolumn{2}{c}{ Data In-situ } & \multicolumn{2}{c}{ Data BMKG } & \multicolumn{2}{c}{ Selisih } \\
\cline { 2 - 7 } $\begin{array}{c}\text { Nama } \\
\text { Titik }\end{array}$ & $\begin{array}{c}\text { Kec. } \\
(\mathrm{m} / \mathrm{s})\end{array}$ & $\begin{array}{c}\text { Arah } \\
(\text { derajat })\end{array}$ & $\begin{array}{c}\text { Kec. } \\
(\mathrm{m} / \mathrm{s})\end{array}$ & $\begin{array}{c}\text { Arah } \\
(\text { derajat })\end{array}$ & $\begin{array}{c}\text { Kec. } \\
(\mathrm{m} / \mathrm{s})\end{array}$ & $\begin{array}{c}\text { Arah } \\
(\text { derajat })\end{array}$ \\
\hline St-1 & 0,38 & 242,50 & 0,24 & 106,91 & 0,14 & 135,59 \\
St-4 & 0,30 & 224,29 & 0,20 & 28,54 & 0,10 & 195,75 \\
\hline
\end{tabular}

Hasil dari perbandingan arus dari data in-situ dan data BMKG tidak memiliki selisih nilai yang besar pada kecepatan namun memiliki perbedaan yang signifikan pada arah arus. Perbedaan arah arus tersebut sebesar $135^{\circ} 35^{\prime} 24^{\prime \prime}$ pada lokasi St1 dan sebesar $195^{\circ} 45^{\prime} 0^{\prime \prime}$ pada titik pengamatan St-4.

Tabel 4.

Hasil Perbandingan Arus Data BMKG dan Data Sentinel-1

\begin{tabular}{|c|c|c|c|c|c|c|c|}
\hline \multirow{2}{*}{$\begin{array}{l}\text { Nama } \\
\text { Titik }\end{array}$} & \multirow{2}{*}{ Tanggal } & \multicolumn{2}{|c|}{ BMKG } & \multicolumn{2}{|c|}{ Sentinel-1 } & \multicolumn{2}{|c|}{ Selisih } \\
\hline & & $\begin{array}{l}\mathrm{Kec} . \\
(\mathrm{m} / \mathrm{s})\end{array}$ & $\begin{array}{c}\text { Arah } \\
\text { (derajat) }\end{array}$ & $\begin{array}{l}\mathrm{Kec} . \\
(\mathrm{m} / \mathrm{s})\end{array}$ & $\begin{array}{c}\text { Arah } \\
\text { (derajat) }\end{array}$ & $\begin{array}{l}\mathrm{Kec} . \\
(\mathrm{m} / \mathrm{s})\end{array}$ & $\begin{array}{c}\text { Arah } \\
\text { (derajat) }\end{array}$ \\
\hline \multirow{3}{*}{ St-1 } & $4-2-2016$ & 0,09 & 154,60 & 0,27 & 163,64 & 0,17 & 9,04 \\
\hline & $16-4-2016$ & 0,06 & 147,14 & 0,38 & 52,30 & 0,32 & 94,84 \\
\hline & $25-4-2016$ & 0,36 & 0,18 & 2,35 & 64,02 & 1,99 & 63,84 \\
\hline \multirow{3}{*}{ St-4 } & $4-2-2016$ & 0,07 & 173,51 & 0,06 & 235,81 & 0,01 & 62,30 \\
\hline & $16-4-2016$ & 0,05 & 152,16 & 0,06 & 108,93 & 0,01 & 43,23 \\
\hline & $25-4-2016$ & 0,29 & 15,15 & 0,78 & 152,43 & 0,49 & 137,28 \\
\hline
\end{tabular}

Hasil dari perbandingan arus dari data BMKG dan data Sentinel-1 dengan tanggal perekaman 4 Februari, 16 April, 25 April memiliki selisih nilai yang besar pada arah dengan nilai $137^{\circ} 16^{\prime} 48^{\prime \prime}$, sementara perbedaan kecepatan terbesar pada tanggal 25 April pada pengamatan St-1 sebesar 1,99 m/s.

Tabel 5.

Hasil Perbandingan Arus Data In-situ dan Data Sentinel-1

\begin{tabular}{cccccc}
\hline \hline \multirow{2}{*}{$\begin{array}{c}\text { Nama } \\
\text { Titik }\end{array}$} & \multirow{2}{*}{ Tanggal } & \multicolumn{2}{c}{ In-situ } & \multicolumn{2}{c}{ Sentinel-1 } \\
\cline { 3 - 6 } & & Kecepatan & Arah & Kecepatan & Arah \\
\hline \multirow{4}{*}{ St-1 } & $4-2-2016$ & - & - & 0,27 & 163,64 \\
& $16-4-2016$ & - & - & 0,38 & 52,30 \\
& $25-4-2016$ & - & - & 2,35 & 64,02 \\
& $22-4-2016$ & 0,38 & 242,50 & - & - \\
& $4-2-2016$ & - & - & 0,06 & 235,81 \\
St-4 & $16-4-2016$ & - & - & 0,06 & 108,93 \\
& $25-4-2016$ & - & - & 0,78 & 152,43 \\
& $22-4-2016$ & 0,30 & 224,29 & - & - \\
\hline \hline
\end{tabular}

Hasil dari perbandingan arus dari data in-situ dan data Sentinel-1 dengan tanggal perekaman 4 Februari, 16 April, 22 April dan 25 April tidak dapat dilakukan, karena kedua data tidak memiliki persamaan pada waktu pengambilan data. Sehingga, pada evaluasi perbandingan data hanya dilakukan pada data in-situ dan data BMKG, serta data BMKG dan data Sentinel-1. Hal tersebut terjadi karena prediksi pada orbit satelit yang sejatinya melakukan pengambilan data pada 22 April 2016 ternyata Sentinel-1 tidak melakukan pengambilan data.

Dari data perekaman arus tersebut, kami sajikan dalam bentuk diagram angin (windrose) berikut.

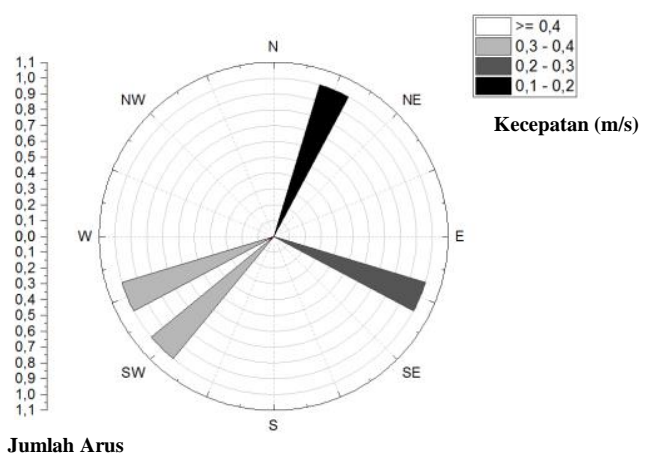

Gambar 7. Rose Diagram Data Arus In-situ dan BMKG

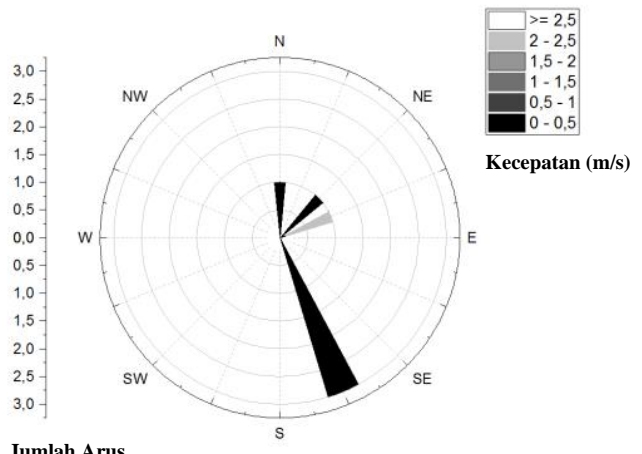

(a)

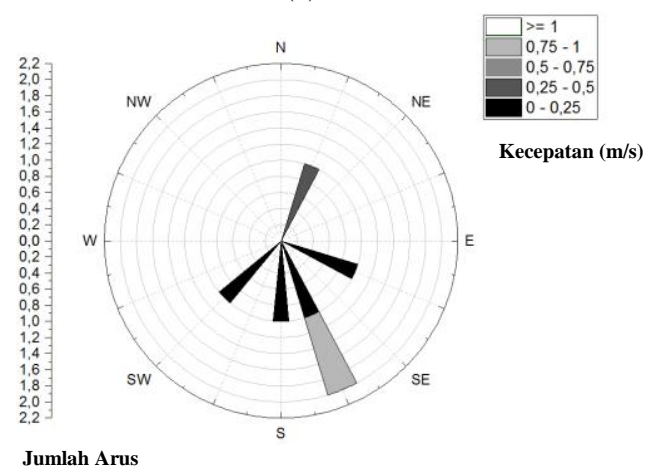

(b)

Gambar 8. Rose Diagram Data Arus BMKG dan Sentinel-1 (a) Lokasi Titik Point 1, (b) Lokasi Titik Point 4

\section{Peta Estimasi Angin dan Arus}

Dari semua data angin dan arus laut dari proses yang telah dilakukan sebelumnya, maka dilakukan pembuatan peta sebagai informasi `mengenai estimasi sebaran angin dan arus di wilayah Perairan Tenggara Sumenep.

Peta estimasi sebaran angin di Perairan Tenggara Sumenep dapat dilihat pada gambar 9 berikut. 


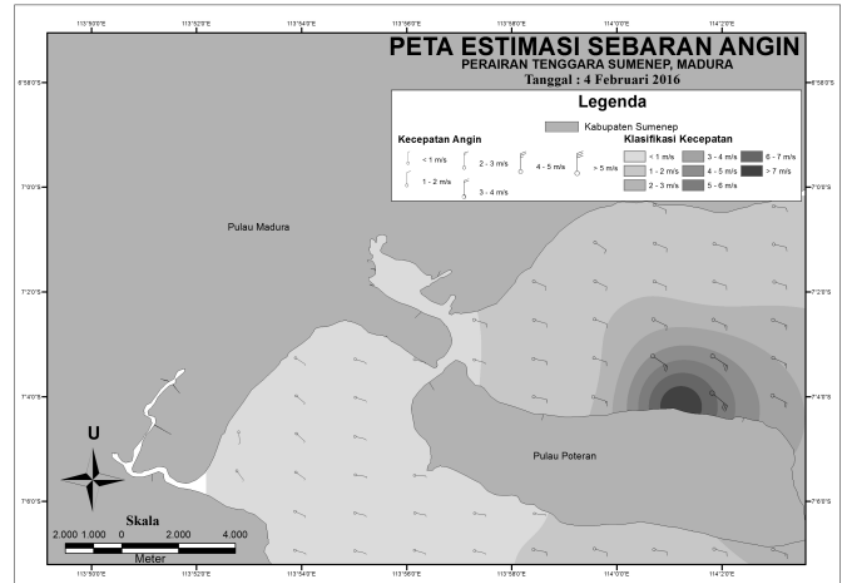

(a)

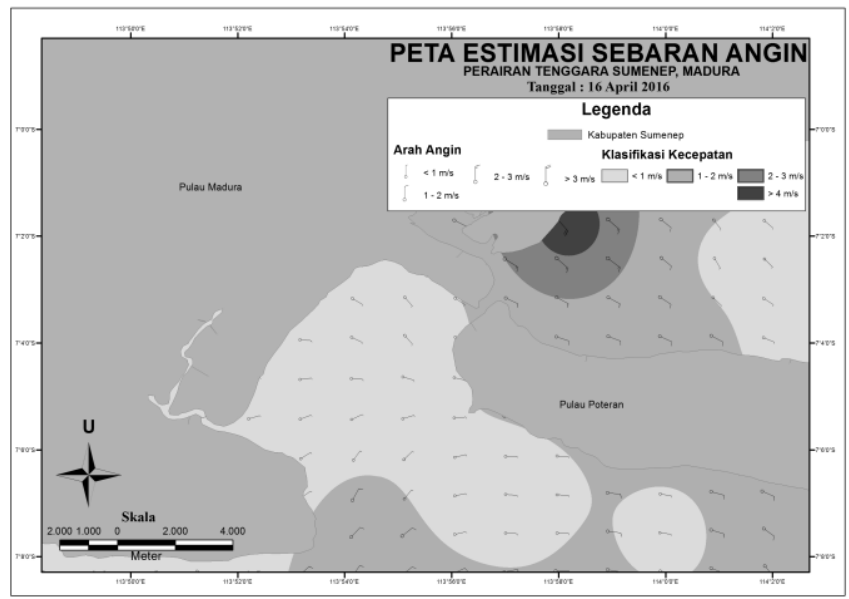

(b)

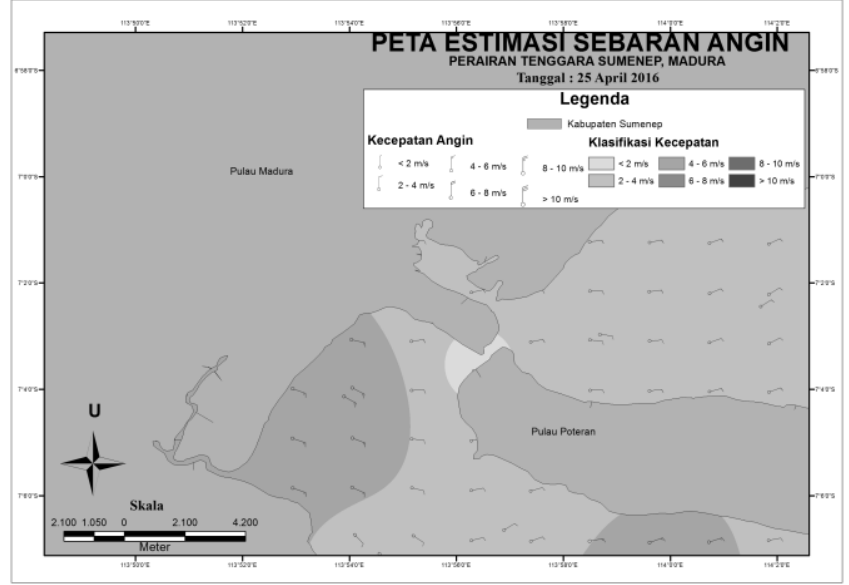

(c)

Gambar 9. Peta Estimasi Sebaran Angin

Pada gambar 9 dapat diketahui bahwa tiap data memiliki variasi angin yang berbeda. Pada tanggal 4 Februari 2016, arah angin berhembus dari timur menuju ke arah barat laut. Sementara tanggal 16 April 2016, angin berhembus dari timur ke arah barat daya selain itu angin pada selat antara Pulau Poteran dan Pulau Madura memiliki arah menuju barat daya. Sementara tanggal 25 April 2016, angin berhembus dari timur menuju ke arah barat daya.

Peta estimasi sebaran arus di Perairan Tenggara Sumenep dapat dilihat pada gambar 10 berikut.

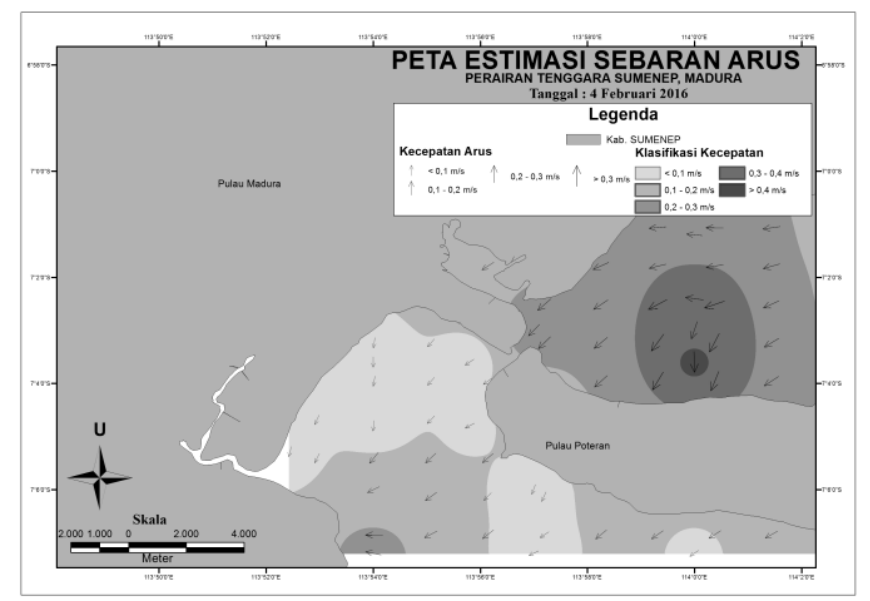

(a)

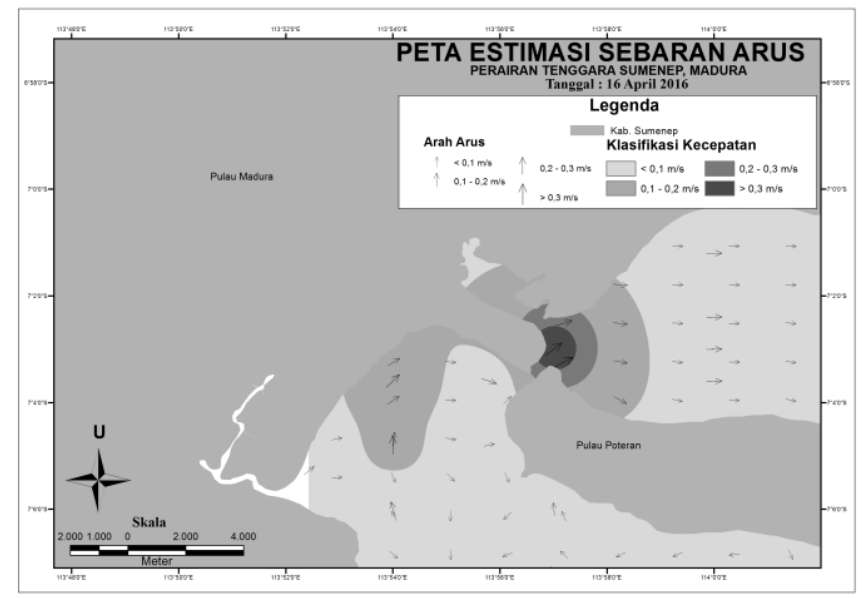

(b)

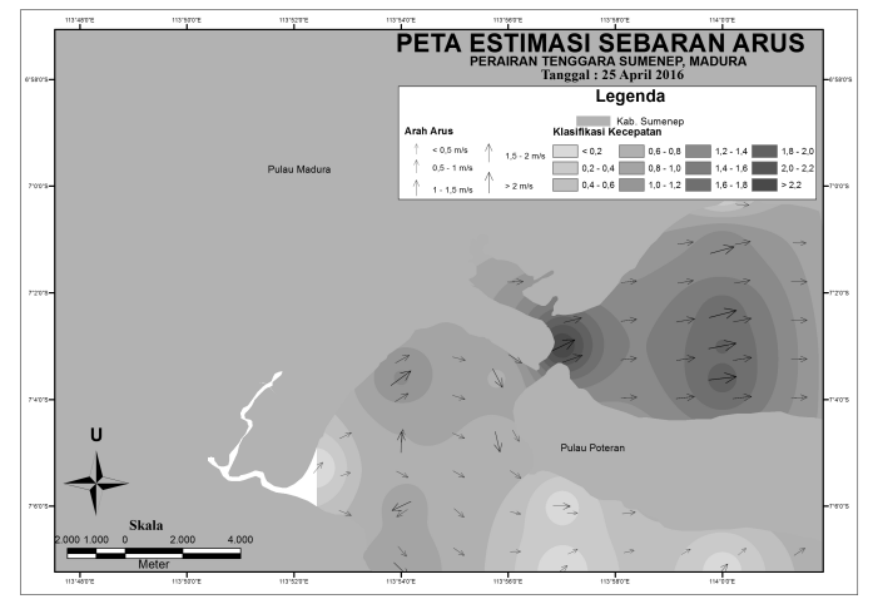

(c)

Gambar 10. Peta Estimasi Sebaran Arus

Pada gambar 10 dapat diketahui bahwa tiap data memiliki variasi arus yang berbeda. Pada tanggal 4 Februari 2016, arah arus berhembus dari timur menuju ke bawah atau ke arah barat laut. Sementara pada tanggal 16 April 2016, arah arus berhembus dari selatan dan cenderung ke arah Tumur Laut ataupun Timur. Sementara pada data tanggal 25 April 2016, arah arus dari Selatan dan Tenggara berhembus ke Timur namun relatif tidak teratur. 


\section{KESIMPULAN DAN SARAN}

Dari hasil ekstraksi fitur dari data Citra Sentinel-1 berupa rata-rata angin pada 4 Februari 2016 sebesar 1,44 m/s dengan arah menuju 29240'12"; 16 April 2016 sebesar 0,99 m/s dengan arah menuju $265^{\circ} 16^{\prime} 12^{\prime \prime}$; dan 25 April 2016 sebesar $3,76 \mathrm{~m} / \mathrm{s}$ dengan arah menuju $264^{\circ} 25^{\prime} 12^{\prime}$. Hasil pemodelan arus pada data Citra Sentinel-1 tanggal 4 Februari 2016 memiliki kecepatan rata-rata $0,18 \mathrm{~m} / \mathrm{s}$ dan arah $198^{\circ} 36^{\prime} 0^{\prime \prime}$; tanggal 16 April 2016 memiliki kecepatan rata-rata $0,08 \mathrm{~m} / \mathrm{s}$ dengan arah $132^{\circ} 22^{\prime} 47,9^{\prime \prime}$; tanggal 25 April 2016 memiliki rata-rata kecepatan $0,95 \mathrm{~m} / \mathrm{s}$ dengan arah rata-rata $92^{\circ} 3^{\prime} 36^{\prime \prime}$.

Hasil perbandingan angin data in-situ dan data BMKG memiliki selisih pada kecepatan di titik 1 sebesar 3,98 m/s dan titik 4 sebesar 3,89 m/s. Hasil perbandingan angin data BMKG dan data Sentinel-1 memiliki selisih nilai terbesar pada kecepatan yaitu $3,01 \mathrm{~m} / \mathrm{s}$. Hasil dari perbandingan arus dari data in-situ dan data BMKG memiliki perbedaan terbesar pada arah arus sebesar $195^{\circ} 45^{\prime} 0^{\prime \prime}$ pada lokasi pengamatan ke-4. Sementara hasil perbandingan angin dan arus pada data in-situ dan data Sentinel-1 tidak dapat dilakukan, karena kedua data tidak memiliki persamaan pada waktu pengambilan data. Hal tersebut terjadi karena prediksi pada orbit satelit yang seharusnya melakukan perekaman data pada 22 April 2016 ternyata tidak melakukan perekaman data, sementara pengambilan data lapangan dilakukan tanggal 22 April 2016. Perbedaan yang besar pada Citra Sentinel-1 karena Citra Sentinel-1 perekaman tanggal 25 April 2016 merupakan citra Single Polarization (VV) yang berbeda dengan citra Sentinel-1 tanggal 4 Februari 2016 dan 16 April 2016. Perbedaan Arah pada pemodelan arus pada pengukuran in-situ dengan data BMKG dikarenakan pada saat pengukuran data in-situ dipengaruhi oleh arus pasang saat bulan purnama sehingga menyebabkan kapal ikut terbawa arus.

\section{UCAPAN TERIMA KASIH}

Penulis mengucapkan terima kasih kepada Lembaga Penelitian dan Pengabdian Kepada Masyarakat (LPPM- ITS) yang telah memberikan dukungan baik moral maupun material sehingga peneliti dapat melakukan survei dan menyelesaikan laporan ini. Penulis juga diperkenankan menyampaikan ucapan terima kasih kepada Badan Meteorologi, Klimatologi, dan Geofisika (BMKG) - Maritim Perak, Surabaya sebagai penyedia data penelitian ini.

\section{DAFTAR PUSTAKA}

[1] Y. Irwanto, "BIG Serahkan Peta NKRI Kepada Kemenkokesra," Badan Informasi Geospasial, 2013. [Online]. Available: http://www.bakosurtanal.go.id/berita-surta/show/big-serahkan-peta-nkrikepada-kemenkokesra. [Accessed 19 Januari 2016].

[2] S. Hutabarat and S. M. Evans, Pengantar Oseanografi, Jakarta: Djambatan, 1986.

[3] Nontji, Laut Nusantara, Jakarta: Djambatan, 1987.

[4] S. Lubis, "Pembangkit Listrik Tenaga Arus laut Bagi Desa Pesisir Tertinggal," 2008. [Online]. Available: http://www.esdm.go.id/berita/323-energi-baru- dan-terbarukan/4310-pembangkit-listrik-tenaga-arus-laut-bagi-desa-pesisirtertinggal-second-opinion.html.

[5] L. Pötter, "Sentinel 1-A Menatap Bumi," 12 Mei 2014. [Online]. Available: http://www.dw.com/id/sentinel-1-a-menatap-bumi/g-17629624. [Accessed 19 Desember 2015].

[6] European Space Agency (ESA), "Sentinel-1 : Oceans and ice," 2015. [Online]. Available:

http://www.esa.int/Our_Activities/Observing_the_Earth/Copernicus/Sentinel1/Oceans_and_ice. [Accessed 19 Desember 2015]. 